\title{
Post-Dotcom IPOs In Germany: After Crisis Developments In Underpricing
}

Wolf Schmuhl, Helmut-Schmidt-University, Hamburg, Germany

Olaf Schnier, Helmut-Schmidt-University, Hamburg, Germany

\begin{abstract}
After the dotcom-breakdown in 2000, German IPOs came to a sudden standstill and recovery took several years. Empirical evidence on German IPO activities so far focused mostly on the preceding new economy bubble. In contrast, this contribution aims at investigating the postdotcom IPO market in Germany, using a sample of 182 IPOs between March 2002 and April 2011. The influences of private equity investors, underwriters and the market segment on the flotation are analyzed. Subsequently, driving factors of underpricing are identified. Our results indicate that especially offering characteristics affect underpricing. Furthermore, the company's age and the industry have a significant impact. Private equity investors, major underwriters and the market segment lost their empirically observable influence on underpricing. For the postdotcom market environment, the results show a shift towards other hot-issue industries, a cooling down of investor sentiments and no significant reduction in ex-post uncertainty concerning new market segments.
\end{abstract}

Keywords: IPO; Underpricing; Private Equity; Underwriter

\section{INTRODUCTION}

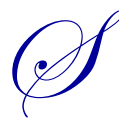

ince a vital stock market is the main requirement for a successful IPO, the issuing volume relies on the economic environment (Jenkinson and Ljungqvist 2001). German IPO activity traditionally is less distinct in comparison to the US or the UK, regarding the number of flotations and volume raised (Black and Gilson 1998). Between 1984 and 1996 the average number of IPOs had been 19.5 per year (Franzke et al. 2003), a remarkably low figure for one of the world's leading economies. This case changed fundamentally in 1997 with the implementation of the Neuer Markt (New Market), a market segment for technology and growth companies. This innovation was responsible for a tremendous increase in IPOs in Germany (see Figure 1). For the first time, young and innovative German enterprises gained direct access to the stock market and therefore to equity supply. The boom, combined with the worldwide information technology hype, led to inappropriate valuations. The burst came in 2000, when the dotcom-crisis arose, heading to the final collapse of the Neuer Markt in 2003. Within the next years, the Deutsche Börse AG (Frankfurt stock exchange) restructured and renamed all market segments. The IPO activity in this time was overshadowed by the aftermath of the dotcom-bubble, resulting in only 12 IPOs from 2002 to 2004 (see Figure 1).

After four years of recovery, the IPO market returned to former strength. The IPO volume from 2006 to 2008 even outperformed the activity before the dotcom-hype (pre-1997). By the end of 2007, first indications of a new financial crisis came up that reached its peak with the bankruptcy of Lehman Brothers. The US housing bubble and the subprime crisis were basically responsible for this financial crisis. Within one decade, this was the second shock for the German IPO market. In comparison to the dotcom-crisis, where the IPO market totally broke down, the IPO activity recovered within two years: in 2010 already 14 companies went public in Germany again. This paper aims to focus on the latest, very recent period of the German IPO market: the time after the dotcom-bubble.

In all kind of market conditions IPOs are accompanied by the underpricing phenomenon. It describes the substantial price jump after listing compared to the issuing price (Ljungqvist 2007). This price revision during the first trading day means a loss of money for the issuer and a gain for investors (Loughran and Ritter 2002). It is a 
well-documented miracle in the existing literature. Hence, the German market is also affected by underpricing, as shown below in Figure 2.

Additionally to its very specific IPO-history, Germany also provides a unique institutional framework for an analysis of underpricing. Elston and Yang (2010) describe these features with high insider ownership, a strong role of banks and a less developed equity market (see Theissen 2003 for an overview of the German equity market). Furthermore, the rearrangement of stock market segments, VCs with a rather short track record and an excessive dotcom-bubble make up an exceptional setting to analyze stock flotations. The case of Germany in the period 20022011 (after crisis developments) also perfectly contributes to three shortcomings of the existing research so far:

- $\quad$ Former analyzes on German IPOs investigated nearly exclusively the Neuer Markt. This segment includes a wide range of dotcom-IPOs within abnormal market conditions (Günther and Rummer 2006) and does not seem to be representative for the German market in general. Studies prior to the bubble years are rare and only provide few insights regarding multivariate analysis. After reorganizing the market segments, the Neuer Markt does not exist anymore. A detailed view on IPOs in the newly created market segments therefore promises new insights regarding flotations in the German institutional setting during non-bubbletimes.

- $\quad$ The reasons for underpricing vary over time. Loughran and Ritter (2004) find a shift from the winner's curse problem and dynamic information acquisition towards agency problems and market conditions. The sample used in this study consists of very recent IPOs from 2002 to 2011, analyzing present developments and the impact of experience gained during the dotcom-period in Germany. Hence, this study aims to identify the lessons learnt as well as the consequences of the excesses in the bubble-period.

- $\quad$ Studies so far provided no clear evidence regarding several research questions and leave various puzzles concerning private equity (PE) involvement, the role of underwriters (UW), market regulation and the hotissue theory. Furthermore, we do not limit our study on the first trading day, but also take post-IPO returns into account.

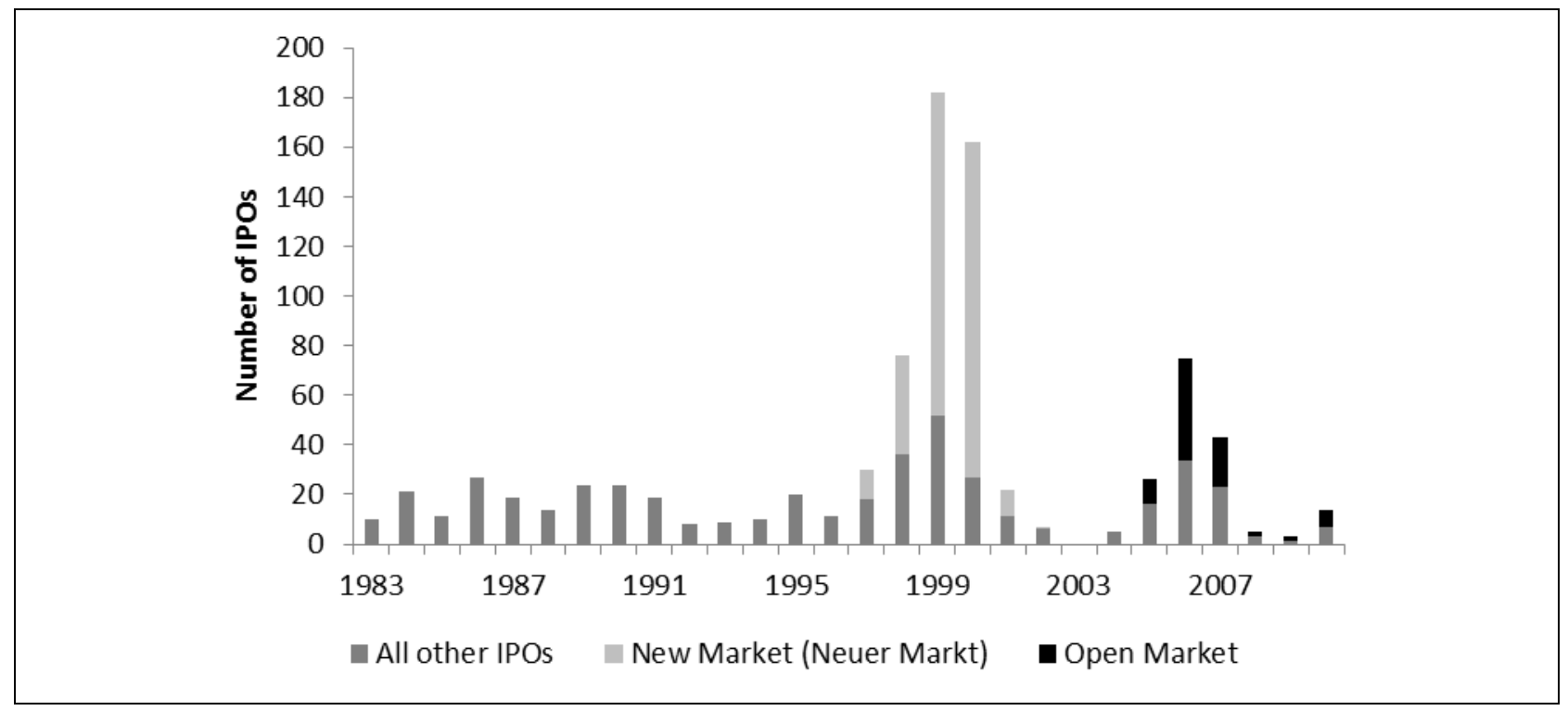

Figure 1. Number of IPOs in Germany and Market Segment of Listing Source: DAI Factbook (2004) and Deutsche Börse AG.

This contribution hence aims at providing evidence on these shortcomings and testing theories with a focus on after crisis developments on the German market. For this purpose, we analyze a unique data sample consisting of 182 German IPOs in the period from March 2002 to April 2011. At first, we check for differences in means regarding PE involvement, major UWs' presence and the market segments. Then, a regression analysis is performed to find possible factors of influence on underpricing as well as short- and medium-term abnormal returns. At that, we employ a variety of 22 independent variables to investigate hypotheses based on theoretical foundations. 
This contribution is organized as follows. The next section outlines the theoretical background of underpricing by presenting the relevant models and their underlying theory. Afterwards, an overview of literature addressing the German as well as European IPO market is given. The subsequent part formulates hypotheses based on the theory presented. The next section introduces the data and variable description as well as the empirical approach, followed by the main results and a discussion. The last section concludes and gives an outlook on further fields of research.

\section{THEORETICAL FOUNDATIONS AND LITERATURE REVIEW}

Underpricing is an intensely analyzed phenomenon within the IPO process and financial market research in general. Ljungqvist (2007) categorizes the theories regarding reasons for underpricing as follows: asymmetric information models, institutional and behavioral models, as well as ownership theories. The asymmetric information theory is the most prominent one, grounding on the winner's curse model (Rock 1986), the ex-ante uncertainty model (Beatty and Ritter 1986) and the signaling theory (Allen and Faulhaber 1989; Welch 1989). They all point out differences in knowledge between issuer, UW and investors.

\section{Private Equity's Certification Role}

The opinions on the role of PE in the IPO process are contrary. According to the definition of the European Private Equity and Venture Capital Association (EVCA), PE includes the following investment stages: venture capital (VC), growth capital, replacement capital, rescue/turnaround capital and buyouts (EVCA 2011). Megginson and Weiss (1991) highlight the participation of PE in the IPO process as a proof of quality for the issuing firm. From this point of view PE fulfills a certification role. On the other hand, following the grandstanding theory, the role of a PE investor is said to be critical. PE investors have incentives to push the IPO process, even though the firm is not ready. IPOs generate cash for new investments and increase the investor's reputation, which is an important factor in the following fundraising. Since PE holdings are of temporary character - the average life-time of a VC-fund has a maximum of 10 years (Gompers and Lerner 2006) - time is of critical relevance. These incentives lead to premature IPOs and therefore to higher underpricing (Gompers 1996; Gompers and Lerner 2006). Former research shows mixed results and provides evidence for both hypotheses (Megginson and Weiss 1991; Lin and Smith 1998; Francis and Hasan 2001; Lee and Wahal 2004).

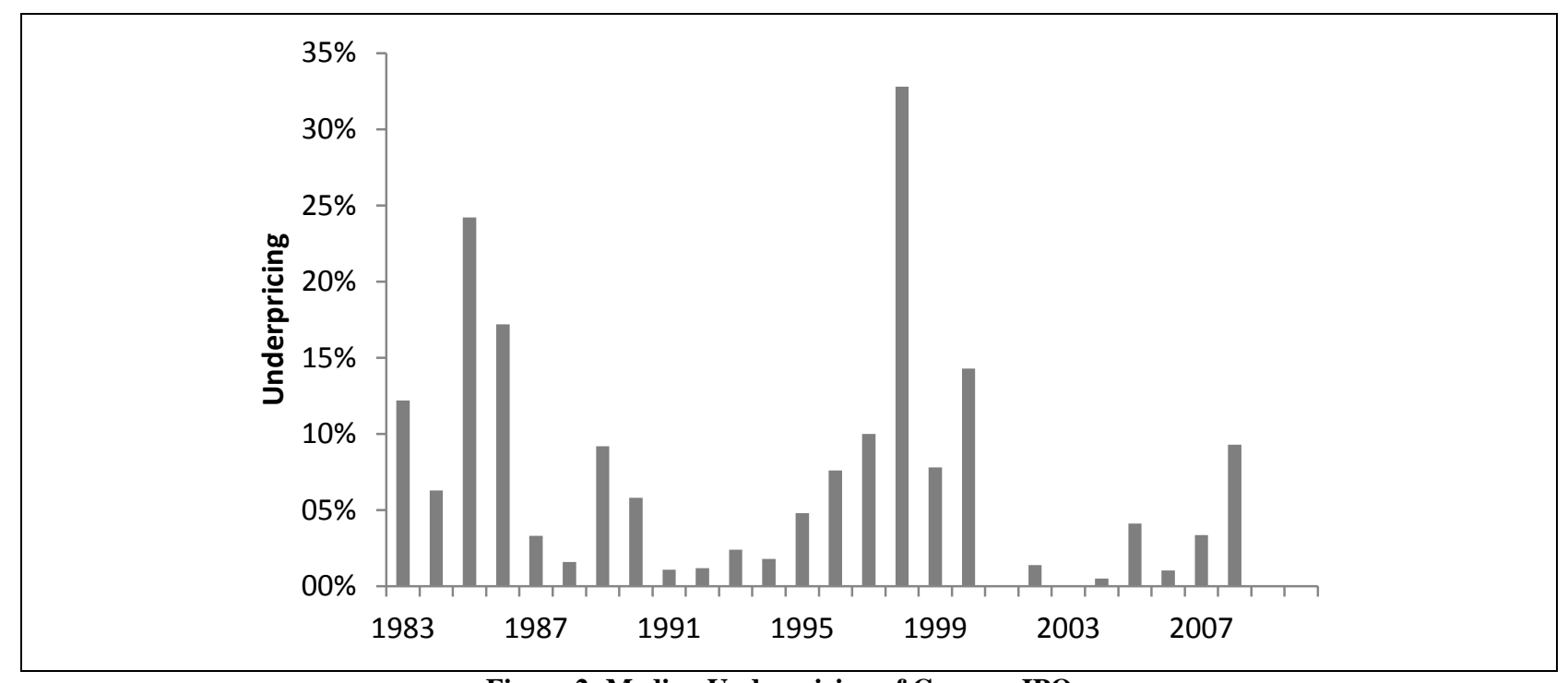

Figure 2: Median Underpricing of German IPOs.

Source: Höllbacher (2011) till 1996, afterwards own calculations. 


\section{Underwriters' Affiliations and Maximization of its Investors' Shares}

The UW is another important institution involved in the IPO process and possibly also influences underpricing. The role of an UW is typically taken by an investment bank (IB). The underwriting process contains a wide range of steps. During the preparation of the IPO main tasks are the due diligence and prospectus drafting followed by the application for listing. The second step is to set up with the market approach including pre-IPO research reports and all kinds of marketing activities, which lead to the final book-closing. In the end, the IB and the issuer have to set the offering price. This is a crucial point regarding profit maximization for both the issuer as well as the investor. In doing so, the IB has to match the interests of both sides (Iannotta 2010).

For Carter and Manaster (1990) the IB's reputation is the key factor influencing underpricing. Only large UWs are able to realize the required analytical activity and network to ensure a successful placement (Hill and Wilson 2006). The costs of such research are high, so only "high value" firms are able to afford this service. Due to the implied accuracy of the firm's valuation, underpricing is reduced and investors do not have to fear negative underpricing. Moreover, Baron (1982) highlights the better information access of IBs in comparison to issuing firms or investors. For IBs, preplanned underpricing is necessary in two ways. First, the underpricing rewards old and attracts future investors and, in a second step, it guarantees the placement of all shares. Contrary to previous studies, Pollock et al. (2004) ground their theory on the well-developed investor-UW-issuer-relationship. Due to these sensitive business relations, the UW cannot take the risk to play an active role in influencing the underpricing process. Ljungqvist and Wilhelm (2003) argue that underpricing is reduced, if the IB holds shares in the issuing company. Such affiliations improve the alignment of UW and issuer. For his own benefit, the UW sets a higher offering price. Especially the German bank-based system could be affected by this theory (Bessler and Kurth 2007). In the dotcom-bubble, VCs and UWs acted as repeat players. Hoberg and Seyhun (2006) argue that both collaborate and exchange favors. VCs, on the one hand, accept higher levels of underpricing, favoring the UWs. On the other hand, UWs provide marketing support and favorable analyst coverage after the IPO. This enables the VCs to sell their retained shares at a high price (Loughran and Ritter 2004; Tykvova and Walz 2007).

\section{Underpricing and Market Regulations}

Another effect on underpricing is set by financial market regulations. Hunger (2005) shows in a European study, that mean underpricing is significantly lower in official markets. Therefore greater corporate transparency reduces the cost of information gathering and - considering the asymmetric information model - decreases the level of underpricing (Hopp and Dreher 2007). For the German market, basic requirements for the regulated market are annual and interim reports in accordance with IFRS, while for the exchange regulated market (open market) an annual report in national GAAP is sufficient (Deutsche Börse AG 2011). The regulated market also has admission criteria regarding the company's age, equity amount and free float according to the German Stock Exchange Admission Regulation (Börsenzulassungsverordnung BörsZulV). Nevertheless, in comparison to these current nonregulated market segments, the Neuer Markt offered a wide range of requirements to ensure transparency: reports on a quarterly basis according to US-GAAP or IAS had to be published (Vitols and Engelhardt 2005).

\section{Investor Activity in Certain Sectors: The Hot Issue Theory}

Some authors argue that focused interest and investors' activity in certain sectors leads to underpricing. During certain times investors develop extraordinary interest for specific industries. Within these "hot issue" periods and industries, the number of IPOs increases. The rising IPO activity leads to overvaluation and therefore to underpricing (Ritter 1984; Ibbotson and Jaffe 1975). The Neuer Markt is a well-known example for this phenomenon, in which investors bought high tech shares without looking at fundamental values.

\section{Recent Developments in the German IPO Market}

Though not catching as much attention as Anglo-American capital markets (recent contributions are provided by Dolvin and Bradford 2008, Arthurs et al. 2008, Guo et al. 2006; Hill and Wilson 2006), the literature provides a variety of studies on the Continental-European IPO market. For example, Kunz and Aggarwal (1994) as well as Drobetz et al. (2003) focus on Switzerland, while Aussenegg (2007) analyzes the Austrian market (other European studies can be found in Engelen and Essen 2010 and Gregoriou 2006). 
There are only few contributions dealing with underpricing in the German market prior to 1997 and hence the beginning of the dotcom-period. Uhlir (1989a) shows that there had been hot-issue markets even then. Uhlir (1989) provides evidence that stocks with high underpricing underperform in the following months. Wasserfallen and Wittleder (1994) as well as Ljungqvist (1997) only find coherence between underpricing and market conditions. Ljungqvist (1997) also detects a positive relation to share retention and a negative to the proceeds. Other authors, such as Schmidt (1988) and Göppl and Sauer (1990) only show descriptive statistics.

The vast majority of following-up studies solely focused on the Neuer Markt. Those contributions were provided by Mayer (2001), Schertler (2002), Leuz (2003), Hunger (2003), Rindermann (2004), Löffler et al. (2005) and Franzke (2004). Showing a lot of contradictory evidence, the authors mostly agreed on the enhancing impact of bear markets and market conditions on underpricing. Some authors found no relation between institutional investors' ownership (such as PE or VC), some detect an underpricing driving effect.

More recent studies are those by Aussenegg et al. (2006), Günther and Rummer (2006), Tykvova and Walz (2007), Dorn (2009) and Elston and Yang (2010). Some found a negative effect of VC and positive coherence with previous market returns and the company's market value. Like German studies, international and European contributions show quite puzzling results (Sentis 2009; Ferretti and Meles 2011). For a summary of studies on Securities Offerings see Eckbo et al. (2007), Cornelli et al. (2006) or Florin and Simsek (2007).

\section{HYPOTHESES}

This section develops five hypotheses (H1 to H5) to be tested in the empirical analysis of the following section. H1 covers prospects about the influence of PE involvement. As shown before, the role of PE in the IPO process is highly controversial. Common hypotheses are set up according to the certification role and the grandstanding theory. In our contribution, we focus on the after crisis effects of PE. Following the grandstanding theory only young and less experienced PE firms need to use their track record as a marketing instrument and therefore have to accelerate the IPO process (Gompers 1996). During the dotcom-bubble many new PE firms were established (Tykvova and Walz 2007). The growth rates in this industry were tremendous and not all firms were experienced enough to make proper investment decisions (Rindermann 2004). Many PE investments were inappropriate and based on mispricing. After the dotcom-bubble, many of these inexperienced firms went out of business and a self-purification of the PE market started (Leopold et al. 2003). As a result, the players described in the grandstanding-process are no longer active on the market. This indicates that grandstanding is perhaps not an issue anymore. Additionally, we assume that during the dotcom-crisis PE firms lost much of their reputation and yet were not able to regain their certification role in the after crisis years. Hence, we argue that PE is no proof of certification and underpricing of PE backed firms does not differ significantly.

H1. PE backed IPOs does not affect underpricing.

Loughran and Ritter (2004) argue that - during the internet bubble period - there had been a shift in the willingness of firms to employ underwriters with a history of underpricing. In exchange, UWs provide analyst coverage and side payments to the CEO. During the dotcom-era the German market featured one of the most severe underpricing in the world (Engelen and Essen 2010) leading to high losses of investors when the bubble burst. Thus, the certification role of major underwriters (Booth and Smith 1986) and their analysts might have suffered badly. This may lead to a situation in which companies no longer accept high amounts of money left on the table, because UWs - due to lost reputation - cannot provide as much demand for their stocks as in former times.

In a bank-based system like Germany major UWs are intensely affiliated. The probability that the UW holds equity stakes in the issuing company is even higher. This leads to reduced underpricing, if a major underwriter is involved. In this contribution, the UW's market shares are used as a surrogate for its reputation (for a detailed explanation see table 2). The post 2002-period became a success story for IBs: never before, they earned such enormous amounts of money. These times ended with the financial crisis in 2008 and the bankruptcy of Lehmann Brothers. Afterwards, competition became more aggressive and IBs had to fight for market shares. In this environment, it was essential to maximize the value of their investors' shares (Loughran and Ritter 2002; Baron and Holmström 1980; Reuter 2006). Due to this competition, each IB tries to serve their investors best, leading to higher 
underpricing during these times. In this context underpricing serves as a marketing instrument for customers. On the other hand, such behavior could have a bad impact on the sensitive relations to the issuer (Dunbar 2000). According to the market conditions in Germany, UW affiliations seem to outweigh the function as a marketing instrument (Muscarella and Vetsuypens 1989; Ljungqvist and Wilhelm 2003).

H2. IPOs using major underwriters are less underpriced.

The main German stock exchange in Frankfurt provides several market segments with differing listing requirements. Regarding the former Neuer Markt, Hunger (2003) notices that its higher listing requirements did not lead to lower underpricing, contradicting the theory of a reduced ex-ante uncertainty. During the dotcombreakdown, the Neuer Markt totally lost its reputation. Hence, there was a need for new market segments which have been installed after the crisis. It seems interesting whether Hunger's observation still holds for the new market segments that divide into the Regulierter Markt (regulated Market by European law) and the Open Market (regulated unofficial market). The experiences during the dotcom-bubble, involving mispricing of start-ups led to higher demand for older and more mature firms. These are more likely to be listed in the regulated market. Due to higher transparency, such regulations should reduce underpricing.

H3. After crisis IPOs listed in the Regulated Market are less underpriced.

According to the hot-issue hypothesis there are periods of special demand for certain industry sectors. Public interest for the IT sector cooled down due to experiences during the burst of the dotcom-bubble. New hotissues could be the biotech or cleantech sectors, because of the growing number of IPOs in these fields of technology. The rising demand for those flotations might also lead to a higher underpricing. In our sample, 12 IPOs belong to the biotech and 15 to the cleantech industry.

H4. IT firms are less underpriced.

H5. Biotech and cleantech IPOs feature more underpricing.

\section{EMPIRICAL ANALYSIS}

Our sample consists of 182 IPOs in the period between March 2002 and April 2011, representing all IPOs in Germany after the dotcom-bubble burst to present. The data is collected out of the Hoppenstedt Aktienführer ${ }^{1}$ (2002-2011), BVK ${ }^{2}$ studies (2007) and publications of German stock exchange. Additional information is taken out of company reports and IPO prospectuses. Stock quotations are gathered from yahoo-finance.

The variables investigated in the empirical part of the study can be separated into dependent variables, company characteristics, IPO-features and market circumstances. The dependent variables are underpricing as well as short- and medium-term buy-and-hold abnormal returns (BHAR). Following a wide range of empirical studies, we define Underpricing of the $\mathrm{i}^{\text {th }}$ IPO as the difference between the issuing price $\left(P_{I}\right)$ and the first trading day's closing price $\left(P_{C}\right.$, see Formula 1$)$.

Underpricing $i=\frac{\left(P_{C, i}-P_{I, i}\right)}{P_{I, i}}$

Since UWs are said to influence trading in the first days of quotation to ensure a positive underpricing to leave a good taste in the mouth (Ibbotson 1975a; Ellis et al. 2000), a look on the short- and medium term development of share prices may show a less distorted picture of the extent of underpricing. Short- and mediumterm abnormal returns are calculated as the stock's return $\left(r_{t}^{i}\right)$ over $\mathrm{n}=20$ and $\mathrm{n}=60$ trading days, corrected for market movements, using the SDAX as benchmark $\left(r_{t}^{\text {Index }}\right)$. The SDAX consists of 50 German smallcaps. The returns include underpricing, assuming that shares are bought at the offering price. Hence, the other dependent variables are created, following Formula 2 (Bessler and Kurth 2007).

\footnotetext{
${ }^{1}$ Annual containing a variety of information regarding shares listed in Germany.

${ }^{2}$ The BVK is the German Private Equity and Venture Capital Association.
} 
Table 1: List of Variables

\begin{tabular}{|c|c|}
\hline Variable & Description \\
\hline Underpricing & Simple Underpricing, see formula (1) \\
\hline $\mathrm{BHAR}_{20}$ & BHAR 20 trading days after IPO, relative to the SDAX \\
\hline $\mathrm{BHAR}_{60}$ & BHAR 60 trading days after IPO, relative to the SDAX \\
\hline LN(Age) & $\log$ of $($ Age +1$)$ \\
\hline PEInvestor & Dummy variable indicating the presence of a private equity investor $(=1,0$ otherwise $)$ \\
\hline MTB & The Market to Book Ratio of the Stock \\
\hline CFperEquity & The Cash Flow to Equity ratio of the Stock \\
\hline IT & $\begin{array}{l}\text { Industry Dummy taking the value of } 1 \text {, if the stock is active in the Information Technology industry } \\
\text { ( } 0 \text { otherwise) }\end{array}$ \\
\hline Biotech & $\begin{array}{l}\text { Industry Dummy taking the value of } 1 \text {, if the stock is active in the biotechnology industry }(0 \\
\text { otherwise) }\end{array}$ \\
\hline Cleantech & Industry Dummy taking the value of 1, if the stock is active in the cleantech industry ( 0 otherwise) \\
\hline $\mathrm{LN}(\mathrm{Vol})$ & log of Issuing volume (no. Of shares offered $\mathrm{x}$ issuing price) \\
\hline UWMShare & Market Share of UW $(>0,5 \%)$, in $\%$, for a more detailed description see Table $2(0$, else $)$ \\
\hline Retention & Percentage of shares Retained by former owners \\
\hline BookB & Dummy for the presence of bookbuilding $(=1,0$ otherwise $)$ \\
\hline WidthBBRange & the width of the offering range relative to the midpoint of the offering range \\
\hline WidthBBPeriod & number of days in which the bookbuilding takes place $(0$, if another procedure is used) \\
\hline AllotmenttoEmission & number of days between the allotment and the first trading day \\
\hline PriceUpdate & The percentage difference between the midpoint of the offering range and the issuing price \\
\hline CeilingLow & Dummy variable taking the value of 1 if the issuing price is the lower ceiling of the offer range \\
\hline CeilingHigh & Dummy variable taking the value of 1 if the issuing price is the upper ceiling of the offer range \\
\hline RegulatedMarket & Dummy taking the value of 1 , if the stock is listed in the regulated market ( 0 otherwise) \\
\hline IndexReturn & SDAX market return, within the last 20 trading days prior to the IPO \\
\hline NoIPOs & number of IPOs within the last 30 days prior to issue \\
\hline MeanUnderpricing & mean underpricing of the IPOs within the last 30 days \\
\hline
\end{tabular}

Note: This table shows the description of the variables used in the empirical analysis.

Table 2: Calculation of UW market shares

\begin{tabular}{|c|c|c|c|c|}
\hline Investment Bank & Volume & Market-Share [\%] & Sole-lead manager & Co-lead manager \\
\hline Deutsche Bank & 6,657 & 26.5 & 7 & 17 \\
\hline Morgan Stanley & 3,359 & 13.4 & 1 & 10 \\
\hline Goldman Sachs & 2,174 & 8.6 & 1 & 6 \\
\hline UBS & 2,128 & 8.5 & 3 & 8 \\
\hline J. P. Morgan & 1,903 & 7.6 & 1 & 7 \\
\hline Credit Suisse FB & 1,420 & 5.6 & 0 & 6 \\
\hline Dresdner Bank & 1,221 & 4.9 & 3 & 6 \\
\hline Citigroup & 1,099 & 4.4 & 1 & 3 \\
\hline Sal. Oppenheim & 865 & 3.4 & 8 & 4 \\
\hline Commerzbank & 686 & 2.7 & 2 & 5 \\
\hline HVB / Uni Credit & 655 & 2.6 & 3 & 0 \\
\hline Equinet & 276 & 1.1 & 9 & 2 \\
\hline Cazenove & 274 & 1.1 & 1 & 2 \\
\hline WestLB & 217 & 0.9 & 6 & 2 \\
\hline LBBW & 209 & 0.8 & 5 & 0 \\
\hline Lehman Brothers & 187 & 0.7 & 0 & 3 \\
\hline ABN AMRO & 167 & 0.7 & 0 & 1 \\
\hline M.M.Warburg & 159 & 0.6 & 3 & 2 \\
\hline Macquarie & 148 & 0.6 & 1 & 1 \\
\hline quirin Bank & 144 & 0.6 & 7 & 0 \\
\hline VEM Aktienbank & 133 & 0.5 & 18 & 0 \\
\hline DZ Bank & 127 & 0.5 & 4 & 0 \\
\hline All Others: 28 banks (sum) & 950 & 2.7 & 59 & 4 \\
\hline
\end{tabular}

Note: This table gives an overview on all UWs with market shares above 0,5\%. Market shares are calculated as the sum of the IPOvolume the bank had been lead manager (see Aussenegg et al. 2006). In case of various co-lead managers, the sum is distributed equally on all lead-managers. Those with a market share above $1 \%$ are treated as major IBs. 
Table 3: Descriptive Statistics

\begin{tabular}{|c|c|c|c|c|c|}
\hline Variable & Arithmetic Mean & Median & Minimum & Maximum & $\begin{array}{l}\text { Standard } \\
\text { Deviation }\end{array}$ \\
\hline Underpricing & 0.054 & 0.015 & -0.233 & 1.000 & 0.143 \\
\hline $\mathrm{BHAR}_{20}$ & 0.027 & -0.018 & -0.453 & 1.459 & 0.232 \\
\hline BHAR $_{60}$ & 0.005 & -0.042 & -0.579 & 1.349 & 0.254 \\
\hline Ln(Age) & 1.849 & 1.946 & 0.000 & 5.318 & 1.133 \\
\hline PEInvestor & 0.451 & & & & 0.499 \\
\hline MTB & 3.574 & 3.042 & -1.193 & 54.000 & 4.180 \\
\hline CFperEquity & 2.416 & 0.210 & -15.594 & 241.538 & 19.763 \\
\hline IT & 0.137 & & & & 0.345 \\
\hline Biotech & 0.066 & & & & 0.249 \\
\hline Cleantech & 0.082 & & & & 0.276 \\
\hline $\mathrm{Ln}(\mathrm{Vol})$ & 3.381 & 3.135 & 0.000 & 7.607 & 1.834 \\
\hline UWMShare & 3.902 & 0.632 & 0.000 & 26.48 & 6.465 \\
\hline Retention & 0.647 & 0.672 & 0.003 & 0.984 & 0.179 \\
\hline BookB & 0.753 & & & & 0.433 \\
\hline WidthBBRange & 0.139 & 0.154 & 0.000 & 0.545 & 0.103 \\
\hline WidthBBPeriod & 7.456 & 7.000 & 0.000 & 95.000 & 7.836 \\
\hline AllotmenttoEmission & 6.681 & 3.000 & 0.000 & 197.000 & 20.874 \\
\hline PriceUpdate & -0.020 & 0.000 & -0.273 & 0.135 & 0.070 \\
\hline CeilingLow & 0.236 & & & & 0.426 \\
\hline CeilingHigh & 0.192 & & & & 0.395 \\
\hline RegulatedMarket & 0.538 & & & & 0.500 \\
\hline IndexReturn & 0.011 & 0.021 & -0.160 & 0.113 & 0.047 \\
\hline NoIPOs & 4.841 & 4.000 & 0.000 & 15.000 & 3.883 \\
\hline MeanUnderpricing & 0.057 & 0.032 & -0.072 & 0.347 & 0.083 \\
\hline
\end{tabular}

Note: This table shows the arithmetic mean, median, minimum, maximum as well as the standard deviation of the sample.

This approach - with a much shorter time horizon than Dorn (2009) or Rindermann (2004) - bears two advantages: first, within only short periods the bias of the chosen benchmark is not material (Sapusek 2000). Second, this contribution focuses on the reasons of underpricing as the difference between issuing price and the company's market value. We think that within at least three months the market will lead to an adequate pricing. It is hard to believe that offering characteristics will drive stock performance in the following years. Our approach primarily aims at correcting for UW stabilization activities (Aggarwal 2000). Additionally, we can check for rebounds caused by investors that only participate in the bookbuilding process to take advantage of the underpricing and sell shortly after the IPO.

To capture company characteristics through fundamental valuations this study involves the market to book ratio $(M T B)$. The MTB is defined as the ratio of the equity's book value and the market capitalization, employing Formula 3.

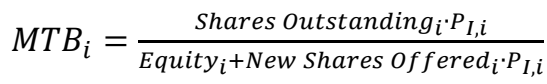

As a second fundamental accounting measure, the cash flow is taken into account. One aim is to correct for earnings management (Teoh et al. 1998, Tykvova 2006). This figure is taken as a proportion in relation to the company's equity for comparability reasons. An overview of all variables used is stated in table 1. For differences in the bookbuilding procedure between Germany and the US, see Aussenegg et al. (2006). To correct for size-effects, some exogenous variables are taken as logarithmic values. Descriptive statistics are shown in table 3. To identify differences in subsamples, we use the Wilcoxon rank sum test (Bauer 1972). Inference of the regression analysis is tested through heteroskedasticity-consistent standard errors proposed by White (1980). Our regression model is structured as followed: 
Dep $=\alpha_{0}+\beta_{1} \ln ($ Age $)+\beta_{2}$ PEInvestor $+\beta_{3}$ MTB $+\beta_{4}$ CFperEquity $+\beta_{5}$ IT $+\beta_{6}$ Biotech $+\beta_{7}$ Cleantech + $\beta_{8} \ln (\mathrm{Vol})+\beta_{9}$ UWMShare $+\beta_{10}$ Retention $+\beta_{11}$ BookB $+\beta_{12}$ WidthBBRange $+\beta_{13}$ WidthBBPeriod + $\beta_{14}$ AllotmentToIssue $+\beta_{15}$ PriceUpdate $+\beta_{16}$ Ceiling $_{\text {Low }}+\beta_{17}$ Ceiling $_{\text {High }}+\beta_{18}$ RegulatedMarket + $\beta_{19}$ IndexReturn $+\beta_{20}$ NoIPOs $+\beta_{21}$ MUP $+\varepsilon_{i}$

To check for multi-collinearity, we calculate variance inflation factors for all independent variables in each regression model. None of these were upon the critical value of 10, indicating that our results bring out valid individual predictors (Kennedy 2003).

\section{RESULTS}

The descriptive statistics including the arithmetic mean, the median, min and max as well as the standard deviation of the 182 observations are stated in table 3. The table shows high standard deviations with the offering volume, indicating a wide range of offering features. Accounting fundamentals also indicate great differences. The mean underpricing of the sample is 5.4\%. After some trading months, mean underpricing gets smaller the longer the period gets, but on the other hand the standard deviation rises. This observation gives support to a development that may lead to the documented long-run underperformance of IPOs (Loughran and Ritter 1995).

The results regarding differences in means are presented in table 4. They indicate significant differences regarding sub-samples segmented by the presence of a PE investor or a major IB as UW and the market segment, in which the shares are listed.

\section{Private Equity}

Companies with PE investors use prestigious UWs far more often than those without. These investors focus especially on the IT and biotech industry. For the issuing procedure, their investment companies tend to have a shorter period between allotment and first trading day. PE investors also seem to choose the IPO day more selective: their investment companies go public within more positive market circumstances and in periods, where IPOs happen more frequently.

Summarizing, there is no clear evidence that PE backed companies differ significantly regarding fundamental figures, such as age, offering volume, cash flow generated or the MTB-ratio. Main differences are the industry focus as well as a more professional IPO procedure. Especially the timing of the market entry is well prepared. There is also no significant evidence to support $H I$ since PE investors do not seem to have any impact on underpricing.

\section{The UW Reputation: Major IB's Influence on the IPO}

Regarding the differences between companies employing a major IB and those that do not, there are more significant observations. Companies with a mean UWMShare above 1\% are backed by PE investors more often (as seen above). These companies tend to have larger emissions and are mainly listed in the regulated market after using a bookbuilding procedure. The fact that the retention rate is smaller cannot be explained by the huge stake of PE backed IPOs in this group, because there seems to be no significant relation between PE investors and retention (see comparison above). Especially in the cleantech-industry, more prestigious UWs are used more often.

The bookbuilding range is bigger, but the time between allotment and first trading day is shorter. These companies generate much more cash flow than the rest of the sample. Though there is no difference in simple underpricing, the short- and medium-term abnormal return differs significantly between both groups. Especially within the first 20 trading days, those companies with major IBs outperform the others and even after 60 trading days this effect still holds. This observation may provide evidence for the assumption that IBs provide stabilization activities for the recently issued company. 
Therefore $H 2$ cannot be supported. Obviously, the major UWs' affiliations do not have a reducing impact on underpricing. However, the short-/medium-term effects induce the opposite: underpricing may be used as a marketing instrument for investors.

\section{Market Segment}

Due to the fact that the regulated market is a new segment for IPOs, it is of special interest to identify what kinds of companies are listed in this market. As seen in the other two comparisons, companies listed in the regulated market are accompanied by more prestigious UWs, also implying that their retention rate is smaller and a bookbuilding procedure is employed more frequently. As a market segment for more mature companies it is no surprise that these companies are larger. Nevertheless, companies going public in the regulated market are not significantly older than the others. The width of the bookbuilding range is larger. An explanation for this might be a more frequent usage of bookbuilding, since the bookbuilding range of a fixed-price offer is defined as 0 in this sample (see table 1). The time between allotment and emission is significantly smaller.

Taking these facts together, IPOs at the regulated market seem to be managed more professionally, by major IBs, using a bookbuilding procedure. Placement is executed in a quicker time span between allotment and emission. These conditions and special rules of the regulated market surprisingly do not have any effects on underpricing, hence providing no evidence for $H 3$.

Table 4: Differences in Means

\begin{tabular}{|c|c|c|c|c|c|c|c|c|c|}
\hline Variable & $\begin{array}{c}\text { With } \\
\text { PEInvestor }\end{array}$ & $\begin{array}{c}\text { Without } \\
\text { PEInvestor }\end{array}$ & p-value & $\begin{array}{c}\text { With } \\
\text { major } \\
\text { IB }\end{array}$ & $\begin{array}{c}\text { Without } \\
\text { major } \\
\text { IB }\end{array}$ & p-value & $\begin{array}{c}\text { IPOs } \\
\text { Regulated } \\
\text { Market }\end{array}$ & $\begin{array}{c}\text { IPOs } \\
\text { non- } \\
\text { Regulated } \\
\text { Market }\end{array}$ & p-value \\
\hline Underpricing & 0.053 & 0.054 & 0.543 & 0.070 & 0.042 & 0.231 & 0.041 & 0.069 & 0.469 \\
\hline $\mathrm{BHAR}_{20}$ & 0.030 & 0.025 & 0.339 & 0.065 & 0.000 & 0.010 & 0.023 & 0.033 & 0.455 \\
\hline BHAR $_{60}$ & -0.006 & 0.014 & 0.638 & 0.050 & -0.027 & 0.015 & 0.010 & -0.001 & 0.199 \\
\hline Ln(Age) & 1.779 & 1.907 & 0.313 & 1.844 & 1.853 & 0.665 & 1.890 & 1.802 & 0.740 \\
\hline PEInvestor & & & & 0.566 & 0.368 & 0.008 & 0.500 & 0.393 & 0.149 \\
\hline MTB & 3.906 & 3.302 & 0.855 & 3.257 & 3.801 & 0.985 & 3.157 & 4.061 & 0.341 \\
\hline CFperEquity & 4.234 & 0.925 & 0.886 & 2.319 & 2.485 & 0.110 & 4.224 & 0.306 & 0.095 \\
\hline IT & 0.207 & 0.080 & 0.013 & 0.118 & 0.151 & 0.532 & 0.122 & 0.155 & 0.531 \\
\hline Biotech & 0.110 & 0.030 & 0.032 & 0.066 & 0.066 & 0.997 & 0.082 & 0.048 & 0.360 \\
\hline Cleantech & 0.085 & 0.080 & 0.898 & 0.145 & 0.038 & 0.010 & 0.102 & 0.060 & 0.301 \\
\hline $\mathrm{Ln}(\mathrm{Vol})$ & 3.614 & 3.191 & 0.114 & 4.896 & 2.295 & 0.000 & 4.531 & 2.041 & 0.000 \\
\hline UWMShare & 5.557 & 2.545 & 0.025 & & & & 6.749 & 0.582 & 0.000 \\
\hline Retention & 0.629 & 0.662 & 0.113 & 0.577 & 0.697 & 0.000 & 0.596 & 0.706 & 0.000 \\
\hline BookB & 0.780 & 0.730 & 0.435 & 0.895 & 0.651 & 0.000 & 0.857 & 0.631 & 0.000 \\
\hline WidthBBRange & 0.148 & 0.130 & 0.366 & 0.160 & 0.123 & 0.024 & 0.162 & 0.111 & 0.000 \\
\hline WidthBBPeriod & 6.524 & 8.220 & 0.265 & 7.105 & 7.708 & 0.802 & 7.020 & 7.964 & 0.849 \\
\hline AllotmenttoEmission & 6.012 & 7.230 & 0.055 & 4.355 & 8.349 & 0.000 & 3.449 & 10.452 & 0.000 \\
\hline PriceUpdate & -0.023 & -0.018 & 0.448 & -0.010 & -0.028 & 0.096 & -0.020 & -0.020 & 0.709 \\
\hline CeilingLow & 0.220 & 0.250 & 0.632 & 0.211 & 0.255 & 0.491 & 0.265 & 0.202 & 0.321 \\
\hline CeilingHigh & 0.159 & 0.220 & 0.298 & 0.276 & 0.132 & 0.015 & 0.214 & 0.167 & 0.419 \\
\hline RegulatedMarket & 0.598 & 0.490 & 0.149 & 0.842 & 0.321 & 0.000 & & & \\
\hline IndexReturn & 0.019 & 0.004 & 0.025 & 0.012 & 0.010 & 0.585 & 0.013 & 0.009 & 0.673 \\
\hline NoIPOs & 5.500 & 4.300 & 0.062 & 4.974 & 4.745 & 0.528 & 4.551 & 5.179 & 0.216 \\
\hline MeanUnderpricing & 0.057 & 0.057 & 0.871 & 0.064 & 0.052 & 0.509 & 0.063 & 0.050 & 0.644 \\
\hline $\mathrm{n}$ & 82 & 100 & & 76 & 106 & & 98 & 84 & \\
\hline
\end{tabular}

Note: This table shows the differences of the arithmetic means of the variables employed and the p-value indicated by the Wilcoxon rank sum test with continuity correction. Bold figures represent significance levels below $10 \%$. 


\begin{tabular}{|c|c|c|c|c|c|c|c|c|c|c|c|c|c|c|c|c|c|c|}
\hline \multirow{3}{*}{$\begin{array}{l}\text { Variable } \\
\text { Dep } \\
\text { (Intercept) }\end{array}$} & St. Beta & t-value & & St. Beta & t-value & & St. Beta & t-value & & St. Beta & t-value & & \multirow{2}{*}{\multicolumn{2}{|c|}{\begin{tabular}{c|c|} 
St. Beta & t-value \\
BHAR $_{60}$ \\
\end{tabular}}} & \multirow{2}{*}{\multicolumn{3}{|c|}{ 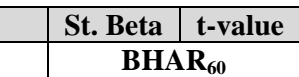 }} & \multirow{3}{*}{ * } \\
\hline & \multicolumn{2}{|c|}{ Underpricing } & & \multicolumn{2}{|c|}{ Underpricing } & & \multicolumn{2}{|c|}{ BHAR $_{20}$} & & \multicolumn{2}{|c|}{ BHAR $_{20}$} & & & & & & & \\
\hline & -0.023 & -0.534 & & -0.006 & -0.154 & & $\begin{array}{l}-0.155 \\
\end{array}$ & \begin{tabular}{|l|}
-1.822 \\
\end{tabular} &. & -0.146 & -1.645 & & $\begin{array}{l}-0.199 \\
\end{array}$ & \begin{tabular}{|l|}
-2.130 \\
\end{tabular} & $*$ & $\begin{array}{l}-0.060 \\
\end{array}$ & -1.185 & \\
\hline LN(Age) & 0.113 & 1.699 & . & 0.110 & 1.884 & . & 0.129 & 1.836 & . & 0.114 & 1.841 & . & 0.124 & 1.797 & . & 0.156 & 2.353 & . \\
\hline PEInvestor & 0.030 & 0.393 & & & & & 0.040 & 0.566 & & & & & 0.037 & 0.524 & & & & \\
\hline MTB & -0.082 & -1.492 & & & & & -0.071 & -1.566 & & & & & -0.051 & -1.208 & & & & \\
\hline CFperEquity & 0.045 & 1.430 & & & & & 0.016 & 0.516 & & & & & -0.003 & -0.084 & & & & \\
\hline IT & -0.125 & -2.052 & $*$ & -0.121 & -2.178 & $*$ & -0.065 & -1.039 & & & & & -0.081 & -1.294 & & & & \\
\hline Biotech & -0.060 & -0.948 & & & & & -0.122 & -1.829 & . & -0.101 & -1.912 & . & -0.115 & -1.653 & & & & \\
\hline Cleantech & 0.124 & 2.259 & $*$ & 0.133 & 2.596 & $*$ & 0.070 & 0.964 & & & & & 0.054 & 0.765 & & & & \\
\hline $\mathrm{LN}(\mathrm{Vol})$ & 0.070 & 0.628 & & & & & 0.353 & 2.652 & $* *$ & 0.378 & 4.214 & $* *$ & 0.369 & 2.860 & $* *$ & 0.179 & 2.932 & $* *$ \\
\hline UWMShare & 0,104 & 1,328 & & 0.093 & 2.016 & $*$ & -0.014 & \begin{tabular}{|l|}
-0.191 \\
\end{tabular} & & & & & -0.068 & -0.951 & & & & \\
\hline Retention & 0.222 & 3.209 & $* *$ & 0.173 & 2.414 & $*$ & 0.178 & 2.142 & $*$ & 0.167 & 1.951 & 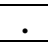 & 0.184 & 2.159 & $*$ & & & \\
\hline BookB & -0.272 & -2.336 & $*$ & -0.330 & -3.883 & $* * *$ & -0.301 & -1.971 & . & -0.300 & -3.274 & $* *$ & -0.304 & -1.982 & $*$ & -0.255 & -2.888 & $* *$ \\
\hline WidthBBRange & -0.042 & -0.411 & & & & & 0.018 & 0.130 & & & & & 0.095 & 0.677 & & & & \\
\hline WidthBBPeriod & -0.096 & -2.084 & $*$ & -0.080 & -2.254 & $*$ & -0.107 & -2.245 & $*$ & -0.088 & -2.310 & $*$ & -0.086 & -1.736 & . & & & \\
\hline AllotmenttoEmission & 0.033 & 0.322 & & & & & 0.069 & 0.631 & & & & & 0.058 & 0.499 & & & & \\
\hline PriceUpdate & 0.068 & 0.543 & & & & & 0.062 & 0.408 & & & & & 0.134 & 0.869 & & & & \\
\hline CeilingLow & 0.031 & 0.466 & & & & & 0.039 & 0.454 & & & & & 0.099 & 1.140 & & & & \\
\hline CeilingHigh & 0.269 & 2.560 & $*$ & 0.321 & 4.493 & $* * *$ & 0.126 & 1.485 & & 0.134 & 2.112 & $*$ & 0.158 & 1.770 & . & 0.237 & 3.705 & $* *$ \\
\hline RegulatedMarket & -0.103 & -1.282 & & & & & -0.147 & -1.620 & & -0.59 & -1.723 & $\cdot$ & -0.115 & -1.276 & & & & \\
\hline IndexReturn & 0.251 & 3.211 & $* *$ & 0.246 & 3.746 & $* * *$ & 0.130 & 1.282 & & & & & 0.042 & 0.441 & & & & \\
\hline NoIPOs & -0.019 & -0.280 & & & & & 0.030 & 0.424 & & & & & -0.095 & -1.337 & & & & \\
\hline MeanUnderpricing & -0.029 & -0.527 & & & & & -0.067 & -1.020 & & & & & -0.061 & -0.974 & & & & \\
\hline Adj. R-squared / (n): & 0.22 & $(182)$ & & 0.25 & $(182)$ & & 0.08 & $(182)$ & & 0.12 & $(182)$ & & 0.09 & $(182)$ & & 0.12 & $(182)$ & \\
\hline
\end{tabular}

Note: This table shows the empirical results out of the regression analysis on model. “.”, “*”, “**”, “***” represent 10\%, 5\%, 1\% and $0,1 \%$ significance levels respectively (bold figures). 


\section{Regression Results: Drivers of Underpricing}

The results of the regression analysis for the three dependent variables - underpricing and short-/mediumterm abnormal returns after 20 resp. 60 trading days - are stated in table 5. Beside the coefficients and t-values for the whole range of variables, we employed a stepwise exclusion of variables (those with the smallest coherence) to test for the robustness of coherences.

The figures stated in table 4 imply that IPOs with PE involvement always employ prestigious UWs. This feature of the German market may raise doubts about the independence of both variables. For our regression analysis, we address this threat on the one hand with the stepwise exclusion of variables; on the other hand, we run our regressions excluding PE resp. $\mathrm{IB}_{\text {big. }}$. The latter results (not stated) do not show any difference regarding the insignificance of both variables.

Variables influencing simple underpricing are especially industry and transaction characteristics. The company's age is positively related to underpricing. The $I T$ sector reduces, while the cleantech industry drives underpricing, providing evidence for $H 4$ and $H 5$ (hot-issues/cold-issues). However, $H 5$ seems not to hold in case of the biotech industry. Regarding the offering characteristics, retention enlarges and bookbuilding reduces underpricing significantly. An enlarging width of the bookbuilding period brings out smaller underpricing, while the variable CeilingHigh leads to higher underpricing. The index return prior to the IPO has a positive effect on underpricing. After stepwise exclusion, the UWMShare also shows positive linkage to underpricing. For all other variables, results regarding the significance are robust.

Looking at the short-term performance after 20 trading days, the companies' age drives stock performance. The intercept also shows a significant negative estimate. A larger issuing volume goes in line with superior performance. Like the previous regressions, retention, bookbuilding and the width of the bookbuilding period influence underpricing in the same directions. While IT and cleantech are not significant, biotech has a negative influence on underpricing. Stepwise exclusion leads to varying results indicating that the relations shown are not as robust as with the simple underpricing: the intercept loses significance, while CeilingHigh and the market segment become significant.

Within 60 trading days after going-public the company's age, the issuing volume, bookbuilding and CeilingHigh have significant influence on out- and underperformance. The intercept indicates that IPOs in general underperform significantly. Less robust are those relations between BHAR and retention.

\section{DISCUSSION}

This study aims not only to identify reasons for underpricing but also to discuss changes in regard to those findings for the bubble period. To make these changes more clearly, table 6 provides an overview on the main results of former studies dealing with the dotcom-bubble and those of our study. The most striking change regarding reasons for underpricing in the Neuer Markt and the after crisis environment is that market sentiments lost most of their influence on valuation. In fact, underpricing is still positively related to the index return prior to the IPO, but neither the number of IPOs nor recent mean underpricing have explanatory power in our sample. This underlines the observation that investor sentiments cooled down considerably. The return of the benchmark index only influences the initial return and not short- and medium-term abnormal returns. Hence, market returns of the time between bookbuilding and first trading day seem to be priced into the first quotations but do not matter for later trading anymore.

However, when regarding investors' interest for certain industries, our results validate the hot-issue hypothesis even in the post-bubble environment. Within our sample, we identified two potential hot-issue industries: the cleantech and biotech sector. The results can only confirm an outstanding demand for the cleantech industry, whereas the biotech sector does not seem to gain special interest in Germany. Biotech only shows a negative coherence once after 20 trading days of listing, therefore findings are only little reliable. As a former bubbleindustry the IT-sector has now become more realistic in market expectations. Due to lessons learned in the NeuerMarkt the valuations came down and today, there is rather an "overpricing" in the $I T$ sector. These results 
considering IT and cleantech are only significant for initial returns. Former research - except Mayer (2001) and Ljungqvist and Wilhelm (2002) - also showed that it is hard to detect robust linkages. In contrary, most European studies found clear evidence for a relation between the IT sector and underpricing in the dotcom-period. Nevertheless, our short-term results are consistent with a strong demand for the cleantech industry and lower-thanaverage demand for $I T$ shares. In the post-dotcom period, investor activities focus on other industries due to changes in the market environment.

The new segments in the German stock market do not influence underpricing, indicating that the regulations are not differing regarding the reduction of information asymmetry. This may imply that the differences in listing requirements are not considerable. This evidence is contrary to Franzke (2004), Günther and Rummer (2006) for the Neuer Markt and contrary to H3. Since the Neuer Markt - despite having the most comprehensive listing requirements - was denoted by the highest underpricing, market segments also may lead to higher demand due to a very positive reputation. As the participants do not seem to honor any of the market segments, this argument also does not seem to hold.

Looking at the firm's age, the positive coherence is remarkable, because an older company is said to bear less risk and hence a lower ex-ante uncertainty. Besides some authors that do not find significant relations, Günther and Rummer (2006) document this expected negative correlation. Only Tykvova and Walz (2007) also show that older firms are more underpriced. Reasons might be found in a higher demand for more mature IPOs that leads to rising valuations. The superior medium-term performance of older companies (as well as larger ones) might provide evidence for this assumption. Our findings regarding the retention rate are also difficult to interpret. The intuition leads to the suggestion that a higher retention rate signals the quality of the IPO and hence reduces ex-ante uncertainty. Nevertheless, we find that underpricing correlates positively with the fraction of shares unsold. This confirms the results of Leuz (2003) and Aussenegg et al. (2006) but is contrarian to those of Günther and Rummer (2006) or Elston and Yang (2010). Bradley and Jordan (2002) argue that the cost per share caused by underpricing drops if a higher fraction of shares is retained by the issuers. Thus, underpricing is not that harmful for former owners. Further, a rising retention rate reduces the number of shares offered and higher underpricing might be caused by a smaller supply meeting a given level of demand (Ritter 2003). Our observation that the coherence still holds after some weeks supports this argumentation.

The market to book ratio (MTB), as an accounting measure, does not explain underpricing in our models (except in one regression). This evidence goes in line with the results of Elston and Yang (2010), while Dorn (2009) Tykvova and Walz (2007) find positive relations. This implies that differences between book and market values are not helpful to capture ex-ante uncertainty. Even the cash flow per equity has no observable impact on underpricing, involving that both fundamentals do not seem to influence neither underpricing nor performance.

Referring to offering characteristics, our study provides various insights. While past publications, such as Löffler et al. (2005), Leuz (2003) or Tykvova and Walz (2007) show a reducing effect of the offering volume on underpricing, those of Dorn (2009), Günther and Rummer (2006), Tykvova and Walz (2007) as well as Elston and Yang (2010) provide evidence that underpricing rises with higher total company's value (Mayer 2001, Schertler 2002, Ljungqvist and Wilhelm 2002 and Aussenegg et al. 2006 find no significant relation). The results at hand indicate positive coherence between the volume issued and abnormal performance after some trading days, indicating that the volume sold does not affect underpricing but begins to matter after trading started. This may be caused by a higher public interest in bigger IPOs. Bookbuilding, CeilingHigh and the bookbuilding period show a strong coherence with underpricing. This evidence shows that the bookbuilding procedure is able to reduce underpricing and that issuing prices set at the upper limit of the offering range lead to positive initial returns (these results go in line with those of Elston and Yang 2010 and Aussenegg et al. 2006). Longer bookbuilding periods seem to lead to a more accurate pricing, since this variable is negatively related to underpricing.

Our analysis finds no evidence to confirm either the certification role or the grandstanding hypothesis for PE investors. Though PE significantly focuses on growth industries and is able to manage an IPO more professionally, their presence does not affect underpricing at all. This evidence goes in line with findings of Mayer (2001), Hack and Lehmann (2006) and Elston and Yang (2010). Beside Schertler (2002), who finds slight evidence that PE involvement leads to higher underpricing, Franzke et al. (2003) and Tykvova and Walz (2007) document 
that underpricing is in positive relation to the rank of the VC. These observations may not be explained by grandstanding but rather a higher affiliation of VCs and UWs (Loughran and Ritter 2004, Hoberg and Seyhun 2006). In case those rather prestigious and experienced PE investors are more likely to have survived the crisis, one could expect the underpricing to rise, if the old coherence still holds. Since our sample does not show this result, these agency conflicts do not seem to matter anymore. Due to bad sentiments during the dotcom-bubble, after-crisisinvestors do not seem to trust the certification role of PE investors. On the other hand, there is no evidence, that PE investors foster the IPO process for their own benefit. The affiliation theory of PE and UWs in the German bankbased market cannot be confirmed. Hence, we do not observe the certification role of PE in the post-dotcom period, supporting H1. This expands former results that were solely focused on the Neuer Markt-period.

\begin{tabular}{|c|c|c|}
\hline Table 6: Evi & $\begin{array}{l}\text { e Neuer Markt (I } \\
\text { Neuer Markt }\end{array}$ & $\begin{array}{l}\text { st-Dotcom Period } \\
\text { Post-Dotcom period }\end{array}$ \\
\hline Age & $-/ \mathrm{o} /+$ & $\mathrm{o} /+$ \\
\hline PE involved & $\mathrm{o} /+$ & o \\
\hline Market to book ratio & $\mathrm{O} /+$ & o \\
\hline Cashflow per Equity & o & o \\
\hline IT & $\mathrm{O} /+$ & - \\
\hline Biotech & & o \\
\hline Cleantech & & + \\
\hline Volume & $\mathrm{o} /-$ & o \\
\hline UWMShare & $-/ \mathrm{o} /+$ & $\mathrm{o} /+$ \\
\hline Retention & $-/ \mathrm{o} /+$ & + \\
\hline Bookbuilding used & & - \\
\hline Width bookbuilding range & - & o \\
\hline Width bookbuilding period & & - \\
\hline Allotment to emission & & o \\
\hline PriceUpdate & $-/+$ & o \\
\hline CeilingLow & & o \\
\hline CeilingHigh & + & + \\
\hline RegulatedMarket & $+($ Neuer Markt $)$ & o \\
\hline IndexReturn & $\mathrm{o} /+$ & + \\
\hline NoIPOs & $\mathrm{O} /+$ & o \\
\hline MeanUnderpricing & $\mathrm{O} /+$ & o \\
\hline
\end{tabular}

Empirical studies regarding the dotcom bubble showed slight evidence that the more prestigious the IB acting as UW, the lower the underpricing. Through this study, we cannot find such results. Our findings induce little evidence for the opposite. Like other studies - e.g. Schertler (2002), Aussenegg et al. (2006), Leuz (2003) or Franzke (2004) -, we do not find a robust influence of the presence of a major UW on underpricing (Günther and Rummer 2006 find a negative one). Nevertheless, it seems that IPOs managed by major UWs differ significantly in the going-public procedure. This observation can be caused by a loss of certification role of major UWs. Investors, who lost enormous sums of money in the Neuer Markt, might not be willing to trust in particular those IBs that accompanied IPOs during the bubble. Even the higher affiliation of UWs in the German bank-based systems does not seem to lead to a reduced information asymmetry and hence to lower underpricing.

Regarding the institutional framework in Germany, our results go in line with these of Elston and Yang (2010) who find no influence of PE or major IBs' involvement on underpricing. The authors argue that German VCs are too young and relatively weak to lower information asymmetry. Though PE became more mature in Germany, we still do not find significant influences. The lack of significance indicates on the one hand, that agency conflicts are not that heavy to lead to a higher underpricing but, on the other hand, the institutions involved are not able to reduce money left on the table.

\section{CONCLUSION}

This contribution investigates the underpricing phenomenon in a post-crisis environment with special emphasis on the role of PE investors, UWs and market segments. Furthermore a large scale of underpricing driving 
factors is analyzed. The data set grounds on 182 IPOs that took place in the German market between March 2002 and April 2011, representing all IPOs of the post-crisis period in Germany.

Within the most recent period, underpricing reduced to a level comparable to that before the dotcom-bubble (see Figure 2). Our sample provides evidence that especially company characteristics, like age and industry, offering characteristics, such as retention rate or the employment of bookbuilding as well as the market environment influence underpricing. There is only slight evidence for an influence of major UWs in the German bank-based market. The most striking change in regard to the bubble-period is the reduction in investor sentiments. The market environment does no longer drive underpricing significantly. Nevertheless the industry-focus of investors seems to have shifted from IT towards cleantech.

This study is limited by its focus on the German market. To shed further light on this issue, the perspective should be broadened with additional countries to get deeper insights in this field of research.

\section{AUTHOR INFORMATION}

Wolf Schmuhl, Institute of Business Administration and International Finance, Helmut-Schmidt-University, Holstenhofweg 85, 22043 Hamburg, Germany. Wolf Schmuhl is Ph.D. student. E-mail: w.schmuhl@gmx.de (Corresponding author)

Dr. Olaf Schnier, Institute of Business Administration and International Finance, Helmut-Schmidt-University, Holstenhofweg 85, 22043 Hamburg, Germany. Dr. Olaf Schnier is research associate. E-mail: schnier@hsu-hh.de

\section{REFERENCES}

1. Aggarwal, R. (2000). Stabilization Activities by Underwriters after Initial Public Offerings, Journal of Finance, 60(3) 1075-1103.

2. Allen, F. \& Faulhaber, G. R. (1989). Signalling by Underpricing in the IPO Market. Journal of Financial Economics, 23(2) 303-323.

3. Arthurs, J. D., Hoskinsson, R. E., Busenitz, L. W. \& Johnson, R. A. (2008). Managerial Agents Watching other Agents: Multiple Acency Conflicts Regarding Underpicing in IPO Firms, Academy of Management Journal, 51(2) 277-294.

4. Aussenegg, W., Pichler, P. \& Stomper, A. (2006). IPO Pricing with Bookbuilding and a When-Issued Market. Journal of Financial and Quantitative Analysis, 41(4) 829-862.

5. Aussenegg, W. (2007). Underpricing and the aftermarket performance of initial public offerings: the case of Austria, In: Gregoriou, G. N. (ed.): Initial Public Offerings : An International Perspective, 187-213. Oxford: Butterworth-Heinemann.

6. Baron, D. A. (1982). Model of the Demand for Investment Banking Advising and Distribution Services for New Issues. Journal of Finance, 37(4) 955-976.

7. Baron, D. A. \& Holmström, B. (1980). The Investment Banking Contract for New Issues Under Asymmetric Information: Delegation and Incentive Problem. Journal of Finance, 35(5) 1115-1138.

8. Bauer, D. F. (1972). Constructing Confidence Sets Using Rank Statistics. Journal of the American Statistical Association, 67(339) 687-690.

9. Beatty, R. P. \& Ritter, J. R. (1986). Investment Banking, Reputation, and the Underpricing of Initial Public Offerings. Journal of Financial Economics, 15(1-2) 213-232.

10. Bessler, W. \& Kurth, A. (2007). Agency Problems and the Performance of Venture-backed IPOs in Germany: Exit Strategies, Lock-up Periods, and Bank Ownership. The European Journal of Finance, 13(1) 29-63.

11. Black, R. \& Gilson, R. (1998). Venture Capital and the Structure of Capital Markets: Bank versus Stock Markets. Journal of Financial Economics, 47(3) 243-277.

12. Booth, J. R. \& Smith, R. L. (1986). Capital Raising, Underwriting and the Certification Hypothesis. Journal of Financial Economics, 15(1-2) 261-281.

13. Bradley, D. J. \& Jordan, B. D. (2002). Partial Adjustment to Public Information and IPO Underpricing. Journal of Financial and Quantitative Analysis, 37(4) 595-616. 
14. BVK (2007). IPO-Markt 2007 [IPO Market 2007]. Berlin: German Private Equity and Venture Capital Association (BVK).

15. Carter, R. B. \& Manaster, S. (1990). Initial Public Offerings and Underwriter Reputation. Journal of Finance, 45(4) 1045-1067.

16. Cornelli, F., Goldreich, D. \& Ljungqvist, A. (2006). Investor Sentiment and Pre-IPO Markets. Journal of Finance, 61(3) 1187-1216.

17. Deutsches Aktieninstitut (DAI) (2004). DAI-Factbook 2004: Statistik, Analysen und Graphiken zu Aktionären, Aktiengesellschaften und Börsen [DAI-Factbook 2004: Statistics, Analyses and Figures on Shareholders, Corporations and Stock Exchanges]. Frankfurt (a. M.): Deutsches Aktieninstitut e.V. (DAI).

18. Deutsche Börse AG (2011). Listing. http://deutsche-boerse.com/dbag/dispatch/en/kir/gdb_navigation/xlc (accessed November 9, 2011).

19. Deutsche Börse AG (2006). Praxishandbuch Börsengang : Von der Vorbereitung bis zur Umsetzung [IPO Best Practice Guide: From Preparation to Realization]. Wiesbaden: Gabler.

20. Dolvin, S. D. \& Jordan, B. D. (2008). Underpricing, Overhang, and the Cost of Going Public to Preexisting Shareholders. Journal of Business and Finance, 35(3\&4) 434-458.

21. Dorn, D. (2009). Does Sentiment Drive the Retail Demand for IPOs?. Journal of Financial and Quantitative Analysis, 44(1) 85-108.

22. Drobetz, W., Kammermann, M. \& Wälchli, U. (2003). Performance of Initial Public Offerings: The Evidence for Switzerland, Working Paper, SSRN: http://ssrn.com/abstract=370400

23. Dunbar, C. G. (2000). Factors Affecting Investment Bank Initial Public Offering Market Share. Journal of Financial Economics, 55(1) 3-41.

24. Eckbo, B. E., Masulis, R. W. \& Oyvind, N. (2007). Securitiy Offerings. In: Vol. 1 Handbook of Corporate Finance : Empirical Corporate Finance, ed. Eckbo, B. E., 233-373. Amsterdam: Elsevier.

25. Engelen, P.-J. \& van Essen, M. (2010). Underpricing of IPOs: Firm-, issue- and country-specific characteristics. Journal of Banking \& Finance, 34(8) 1958-1969.

26. Ellis, K., Michaely, R. \& O'Hara, M. (2000). When the Underwriter is the Market Maker: An Examination of Trading in the IPO Aftermarket. Journal of Finance, 55(3) 1039-1074.

27. Elston, J. A., \& Yang, J. J. (2010). Venture Capital, Ownership Structure, Accounting Standards and IPO Underpricing: Evidence from Germany. Journal of Economics and Business, 62(6) 517-536.

28. EVCA (2011). EVCA Yearbook: Pan-European Private Equity \& Venture Capital Activity Report. Brussels: EVCA.

29. Ferretti, R. \& Meles, A. (2011). Underpricing, Wealth Loss for Pre-Exiting Shareholders and the Cost of Going Public: The Role of Private Equity Backing in Italian IPOs. Venture Capital, 13(1) 23-47.

30. Florin, J. \& Simsek, Z. (2007). The Effects of Moral Hazard and Adverse Selection on the Pricing and Underpricing of Initial Public Offerings. Venture Capital, 9(2) 127-143.

31. Francis, B. B. \& Hasan, I. (2001). The Underpricing of Venture and Nonventure Capital IPOs: An Empirical Investigation. Journal of Financial Services Research, 19 (2/3) 99-113.

32. Franzke, S., Grohs, S. \& Laux, C. (2003). Initial Public Offerings and Venture Capital in Germany. CFS Working Paper 26.

33. Franzke, S. (2004). Underpricing of Venture-Backed and non Venture-Backed IPOs: Germany's Neuer Markt. In: The Rise and Fall of Europe's New Stock Markets (Advances in Financial Economics, Volume 10), ed. Giudici, G. \& Roosenboom, P., 201-230. Amsterdam: Elsevier.

34. Gompers, P. A. (1996). Grandstanding in the Venture Capital Industry. Journal of Financial Economics, 42(1) 133-156.

35. Gompers, P. A. \& Lerner, J. (2006). The Venture Capital Cycle. Cambridge (Mass.): MIT Press.

36. Göppl, H. \& Sauer, A. (1990). Die Bewertung von Börsenneulingen: Einige empirische Ergebnisse [Evaluation of New Issues: Empirical Results], In: Ahlert, D., Franz, K.-P. \& Göppl, H. (eds.): Finanz- und Rechnungswesen als Führungsinstrument, 157-178, Wiesbaden: Gabler.

37. Gregoriou, G. N. (2006). Initial Public Offerings : An International Perspective, Oxford: ButterworthHeinemann.

38. Günther, S. \& Rummer, M. (2006). The hot-issue period in Germany: what factors drove IPO underpricing?, In: Gregoriou, G. N. (ed.) Initial Public Offerings : An International Perspective, 215-245, Oxford: Butterworth-Heinemann. 
39. Guo, R.-J., Lev, B. \& Shi, C. ( 2006). Explaining the Short- and Long-Term IPO Anomalies in the US by R\&D. Journal of Business Finance \& Accounting, 33 (3\&4) 550-579.

40. Hack, A. \& Lehmann, E. (2006). The role of venture capitalists in IPO performance: empirical evidence from German IPO data, In: Gregoriou, G. N. (ed.): Initial Public Offerings : An International Perspective, 312-322, Oxford: Butterworth-Heinemann.

41. Hill, P. \& Wilson, N. (2006). Value Gains on Flotation and IPO Underpricing. Journal of Business Finance \& Accounting, 33(9\&10) 1435-1459.

42. Hoberg, G. \& Seyhun, H. N. (2006). Do Underwriters Collaborate with Venture Capitals in IPOs? Implications and Evidence, Working Paper, SSRN: http://ssrn.com/abstract=690421

43. Höllbacher, A. (2011). Das Underpricing-Phänomen und die Sekundärmarktperformance von Initial Public Offerings (IPOs) am deutschen Kapitalmarkt - Eine empirische Studie für den Zeitraum 1983-2009 [The Underpricing Phenomenon and Secondary Market Performance in the German Capital Market - An Empirical Study for the period from 1983-2009]. Corporate Finance biz, 3(2) 165-175.

44. Hopp, C. \& Dreher, A. (2007). Do Differences in Institutional and Legal Environment Explain CrossCountry Variations in IPO Underpricing?. CESIFO Working Paper 2082.

45. Hoppenstedt Aktienführer (2002-2011). Hoppenstedt Aktienführer [Hoppenstedt Stock Performance Guide]. Darmstadt: Hoppenstedt Firmeninformationen.

46. Hunger, A. (2003): Market Segmentation and IPO-Underpricing: The German Experience, Working Paper, SSRN: http://ssrn.com/abstract $=496584$

47. Hunger, A. (2005). IPO-Underpricing im Kontext einer vertikalen Marktsegmentierung [IPO Underpricing and Vertical Market Segmentation]. Berlin: Duncker \& Humblot.

48. Iannotta, G. (2010). Investment Banking: A Guide to Underwriting and Advisory Services. Heidelberg: Springer.

49. Ibbotson, R. G. \& Jaffe, J. F. (1975). " Hot Issue" Markets. Journal of Finance, 30(4) 1027-1042.

50. Ibbotson, R. G. (1975a). Price Performance of Common Stock New Issues. Journal of Financial Economics, 2(3) 235-272.

51. Jenkinson, T. \& Ljungqvist, A. (2001). Going Public: The Theory and Evidence on how Companies Raise Equity Finance. Oxford: Oxford Univ. Press.

52. Kennedy, P. (2003). A Guide to Econometrics. Malden: Blackwell.

53. Kunz, R. M. \& Aggarwal, R. (1994). Why initial public offerings are underpriced: Evidence from Switzerland. Journal of Banking \& Finance, 18(4) 705-723.

54. Lee, P. M. \& Wahal, S. (2004). Grandstanding, certification and the underpricing of venture backed IPOs. Journal of Financial Economics, 73(2) 375-407.

55. Leopold, G. H., Frommann, H. \& Kühr, T. (2003). Private Equity - Venture Capital : Eigenkapital für innovative Unternehmer [Private Equity - Venture Capital : Equity for Innovative Entrepreneurs]. München: Vahlen.

56. Leuz, C. (2003). IAS Versus U.S. GAAP: Information Asymmetry-Based Evidence from Germany's New Market. Journal of Accounting Research, 41(3) 445-472.

57. Lin, T. H. \& R. L. Smith (1998) Insider reputation and selling decisions: the unwinding of venture capital investments during equity IPOs. Journal of Corporate Finance, 4(3) 241-263.

58. Ljungqvist, A. P. (1997). Pricing Initial Public Offerings: Further Evidence from Germany. European Economic Review, 41(7) 1309-1320.

59. Ljungqvist, A. P. (2007). IPO Underpricing. In: Vol. 1 Handbook of Corporate Finance : Empirical Corporate Finance, ed. Eckbo, B. E., 375-422. Amsterdam: Elsevier.

60. Ljungqvist, A. P. \& Wilhelm, W. J. Jr. (2003). IPO Pricing in the dot-com bubble. Journal of Finance, 58(2) 723-752.

61. Löffler, G., Panther, P. F. \& Theissen, E. (2005). Who Knows What When? The Information Content of the pre-IPO Market. Journal of Financial Intermediation, 14(4) 466-484.

62. Loughran, T. \& Ritter, J. R. (1995). The New Issues Puzzle. Journal of Finance, 50(1) 23-51.

63. Loughran, T. \& Ritter, J. R. (2002). Why don't Issuers get Upset about Leaving Money on the Table in IPOs?. Review of Financial Studies, 15(2) 413-443.

64. Loughran, T. \& Ritter, J. R. (2004). Why has IPO Underpricing Changed over Time?. Financial Management, 33(3) 5-37. 
65. Mayer, M. D. (2001). Venture Capital Backing als Qualitätsindikator beim IPO am Neuen Markt? [Is Venture Capital Participation an Indicator for IPO Quality on the Neuer Markt?]. Zeitschrift für Betriebswirtschaft, 71(9) 1043-1063.

66. Megginson, W. L. \& Weiss, K. A. (1991). Venture Capitalist Certification in Initial Public Offerings. Journal of Finance, 46(3) 879-903.

67. Muscarella, C. J. \& Vetsuypens, M. R. (1989). A Simple Test of Baron's Model of IPO Underpricing. Journal of Financial Economics, 24(1) 125-135.

68. Pollock, T. G., Porac, J. F. \& Wade, J. B. (2004). Constructing Deal Networks: Brokers as Network Architects in the US IPO Market and Other Examples. Academy of Management Review, 29(1) 50-72.

69. Reuter, J. (2006). Are IPO Allocations for Sale? Evidence from Mutual Funds. Journal of Finance, 61(5) 2289-2324.

70. Rindermann, G. (2004). Venture Capitalist Participation and the Performance of IPO Firms: Empirical Evidence from France, Germany and the UK. Frankfurt (a.M.): Lang.

71. Ritter, J. R. (1984). The Hot Issue Market of 1980. Journal of Business, 57(2) 215-240.

72. Ritter, J. R. (2003). Investment Banking and Securities Issuance, In: Handbook of the Economics of Finance, Constantinides, G. M., Harris, M. \& Stulz, R. (eds.), 253-304, Amsterdam: Elsevier.

73. Rock, K. (1986). Why new Issues are Underpriced. Journal of Financial Economics, 15(1-2) 187-212.

74. Sapusek, A. (2000). Benchmark-Sensitivity of IPO Long-Run Performance: An Empirical Study for Germany. Schmalenbach Business Review, 52(4) 374-405.

75. Schertler, A. (2002). The Certification Role of Private Equity Investors: Evidence from Initial Public Offerings on the Nouveau Marché and the Neuer Markt. EIFC Working Paper, No. 02-10.

76. Sentis, P. (2009). Insider Trading, Pricing and the Long-run Performance of IPOs: Evidence from the French Market. Venture Capital, 11(2) 107-132.

77. Schmidt, R. H. (1988). Underpricing bei deutschen Erstemissionen 1984/85. Zeitschrift für Betriebswirtschaft, 58(11) 1193-1203.

78. Teoh, S. H., Welch, I. \& Wong, T. J. (1998). Earnings Management and the Long-Run Market Performance of Initial Public Offerings. Journal of Finance, 63(6) 1935-1974.

79. Theissen, Erik (2003): Organized Equity Markets in Europe, Working Paper.

80. Tykvova, T. (2006). IPOs and earnings management in Germany, In: Initial Public Offerings : An International Perspective, Gregoriou, G. N. (ed.), 281-296, Amsterdam: Butterworth-Heinemann.

81. Tykvova, T. \& Walz, U. (2007). How Important is Participation of Different Venture Capitalists in German IPOs?. Global Finance Journal, 17(3) 350-378.

82. Uhlir, H. (1989). Der Gang an die Börse und das Underpricing-Phänomen: Eine empirische Untersuchung deutscher Emissionen (1977-1987). Zeitschrift für Bankrecht und Bankwirtschaft, 1(1) 2-15.

83. Uhlir, H. (1989a): Going Public in the F.R.G., In: A Reappraisal of the Efficiency of Financial Markets, Guimaraes, R. M., Kingsman, B. G. \& Taylor, S. J. (eds.), 369-393, Heidelberg: Springer.

84. Vitols, S. \& Engelhardt, L. (2005). National Institutions and High Tech Industries: A Varieties of Capitalism Perspective on the Failure of Germany's "Neuer Markt". WZB : Social Sience Research Center Berlin, SP II 2005 - 03.

85. Wasserfallen, W. \& Wittleder, C. (1994). Pricing Initial Public Offerings in Germany: Evidence from Germany. European Economic Review, 38(7) 1505-1517.

86. Welch, I. (1989). Seasoned Offerings, Imitation Costs and the Underpricing of Initial Public Offerings. Journal of Finance, 44(2) 421-449.

87. White, H. (1980). A Heteroskedasticity-Consistent Covariance Matrix Estimator and a Direct Test for Heteroskedasticity. Econometrica, 48(4) 817-838. 